\begin{tabular}{|c|c|c|}
\hline & Int.J.Curr.Microbiol.App.Sci (2016) 5(10): 891-909 & \\
\hline & International Journal of Current Microbiology and Applied Sciences & \\
\hline & ISSN: 2319-7706 Volume 5 Number 10 (2016) pp. 891-909 & \\
\hline $\begin{array}{l}\text { EXCELLENT } \\
\text { PUBLISHERS }\end{array}$ & Journal homepage: http://www.1jcmas.com & \\
\hline
\end{tabular}

Original Research Article

http://dx.doi.org/10.20546/ijcmas.2016.510.097

\title{
Anticancer and Antibacterial Activity of Ganoderma lucidum
}

\author{
A. Thameem Fathima* and M. Reenaa \\ Department of Microbiology, Ethiraj College for Women, Chennai- 600008, Tamil Nadu, India \\ *Corresponding author
}

\section{Keywords \\ Anticancer, Antibacterial, Ganoderma lucidum, Hep G2, E.coli, Micrococcus luteus, Bacillus thuringiensis, Pseudomonas flourescens.}

\begin{tabular}{l}
\hline Article Info \\
\hline Accepted: \\
25 September 2016 \\
Available Online: \\
10 October 2016
\end{tabular}

\section{A B S T R A C T}

Ganoderma lucidum is considered as one of the richest sources of natural antibiotics and various species of them inhibit the growth of a wide diversity of micro organisms. The pharmacological activities of Ganoderma lucidum, especially its intrinsic immunomodulating and anti- tumor properties have been well documented. Ganoderma has been used in the folk medicine of China and Japan for 4,000 years to treat the liver diseases such as Hepatitis, Nephritis, Arthritis, Gastric ulcers. It is also believed that the Ganoderma lucidum acts as an immunological agent and has been as a natural adjuvant for Immunotherapy. Based upon its effective components, this mushroom was selected for studying the anticancer as well as antibacterial study. The present study is to check the anticancer and antibacterial activities of ethanolic, methanolic and aqueous extracts of G.lucidum. The dried mushroom sample was powdered and extracted with ethanol, methanol and aqueous extracts using Soxhelet apparatus in the laboratory. Vero and Hep G2 liver cancer cell lines were used for determining the cytotoxic and anticancer activity (MTT ASSAY). From the MTT Assay, it was observed that $53.96 \%$ of inhibition of cancer cells from the dilution of $15.6 \mu \mathrm{g} / \mathrm{ml}$ in methanolic extracts of G.lucidum, $52.38 \%$ of inhibition was obtained from the dilution of $31.2 \mu \mathrm{g} / \mathrm{ml}$ in ethanol extracts of G.lucidum, $50.75 \%$ of inhibition was obtained from the dilution of $62.5 \mu \mathrm{g} / \mathrm{ml}$ in aqeous extracts of G.lucidum, It was concluded that the methanolic extracts showed inhibition(IC 50) of 53.96\% at the least dilution of $15.6 \mu \mathrm{g} / \mathrm{ml}$, when compared to the ethanolic and aqueous extracts of G.lucidum. For checking the antibacterial activities of G.lucidum, Bacillus thuringiensis, Micrococcus luteus, Pseudomonas flourescens, and E.coli were selected randomly. The methanolic extract of G.lucidum showed about $20 \mathrm{~mm}$ of zone of inhibition in the Pseudomonas flourescens (MTCC 103) from the dilution of $25 \mu \mathrm{g} / \mathrm{ml}$ and $10 \mathrm{~mm}$ of zone of inhibition was observed in Escherichia coli, which was isolated from UTI patients from the dilution of $25 \mu \mathrm{g} / \mathrm{ml}$. The ethanolic and aqueous extracts were least effective against all the strains. From these studies the methanolic extracts of Ganoderma lucidum can be fruitfully applied and used as the more effective and competent antimicrobial agent. Thus this edible mushroom can be used as antimicrobial agent in the expansion of new drug therapy for the liver diseases. 


\section{Introduction}

Mushrooms are the macro fungi with the distinctive basidiomata or ascomata which can be either hypogeus or epigeous, large enough to be seen with the naked eye and to be picked up by the hand. The number of different kinds of mushrooms in the earth is estimated around 1, 40,000. Around 2,000 of them are edible and 25 species are largely used as foods, being produced in commercial scale. Mushrooms resemble plants in that they cannot move on their own and they have cell walls. Compared to Fungi, the cell wall of fungi composed of Chitin and not cellulose, and fungi do not carry out the photosynthesis. Instead fungi absorb food and nutrients from their surroundings (Andreia et al., 2013).

A mushroom is merely the fruiting body of a much larger fungal colony. Fruiting bodies are reproductive structures that grove above the ground to release spores. Fungal colonies composed of mycelium, a threadlike network that grow underground or in the wood. It is through the mycelium that the fungus absorbs nutrients from its environment. Nutrient absorption takes place in two stages: first the mycelium secretes enzymes that break down plants, animal matter and components in the soil into usable food for the fungal colony, as well as for the surrounding trees and plants. Next, the mycelium absorbs the ensuing nutritional matter it needs to fuel growth.

Mushrooms are the nature's recyclers, breaking down plant and animal matter to release the carbon and other nutrients locked inside. In the early spring the fungi invades the composted leaves and break them down into food for the new spring growth of plants and trees. Many fungi are symbionts, helping the plants to obtain vital nutrients. As the mycelia of the fungi grow through the soil like a net of fingers, they absorb and concentrate nutrients, such as phosphorus and water. Then when the mycelia wrap around the plant roots, even entering the plant's cells, the plants can absorb these concentrated nutrients straight from the fungus. Thus the plant's capabilities are absorbing greatly increased. In return, the fungus can absorb complex compounds that the plant makes, such as sugars and amino acids. Thus, both the plant and fungi gets benefited.

The fruit of this complex process are mushroom, which can benefit the immune system and provide many health benefits for humans. In particular, compounds called hetero polysaccharides - large, complex, branched, chain like molecules built from many smaller units of sugar molecules have been intensively studied for their anti- tumor and immune stimulating properties. Beta glucans are the polysaccharides found in mushrooms that are known as "biological response modifiers" because of their ability to activate the immune system. They also reportedly lower cholesterol, aid in wound healing, help prevent infections and are an adjuvant in cancer treatments.

Smaller compounds such as terpenes and steroids have also been found. A great number of polysaccharides and protein bound polysaccharides have been shown to have antibiotic and antiviral properties, as well as the ability to lower blood pressure and reduced blood levels of lipids and sugar. These active compounds make many fungi useful for treating infections, flu, and diabetes and heart conditions.

The mushrooms are poor in calories and rich in protein fibers, carbohydrates, and important vitamins such as Thiamin, Riboflavin, Ascorbic acid and minerals. They are usually considered as functional foods or nutraceutical products. Mushrooms 
contains many substances and many of them could have some biological activity and those are such as antioxidants, antitumor/anticancer, antimicrobial, immuno modulatory, anti inflammatory actions, anti atherogenic, and hypoglycemic actions.

Among them, the Chinese mushroom called as Ganoderma lucidum is an excellent medicinal mushroom which is also called as 'Spirit plant'. It is commonly known as 'Reishi' in Japan and 'Zing-Zhi' or 'Spirit plant' in China, where it is also referred to the "Plant of Mortality". Lucidum means shiny or brilliant which refers to the appearance of the fungus fruiting body, which has a modeled, varnished look. Ganoderma has been used in the folk medicine of China and Japan for 4,000 years to treat the liver diseases such as Hepatitis, Nephritis, Arthritis, Gastric ulcers. The extracts of G.lucidum have potent anti oxidant and radical - scavenging effects, which contribute to the hepatoprotection. When compared to other species of Ganoderma, G.lucidum has more efficacies to treat the hepatic injuries caused by various factors.

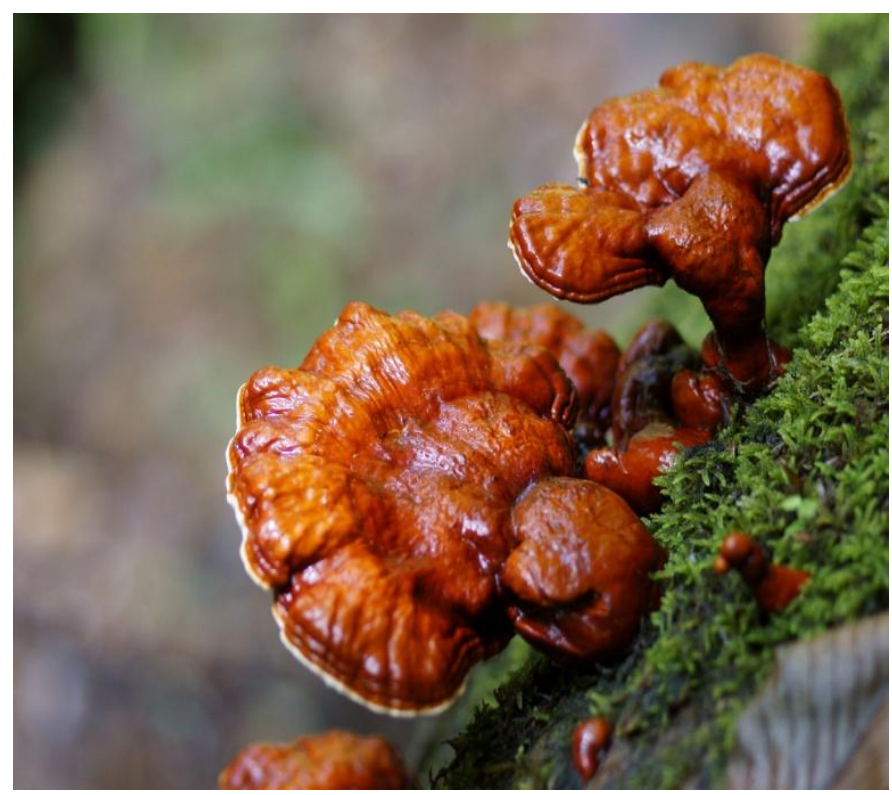

Ganoderma lucidum

The liver is a large, complex organ that is well designed for its central role in carbohydrates, proteins and fat metabolism. It is the site where the waste products of metabolism, such as ammonia, are detoxified. In conjunction with the spleen it is involved in the destruction of remnants of the red blood cells and with the recycling of their constituents. It is responsible for synthesizing and secreting bile and for synthesizing lipoproteins and plasma proteins, including clotting factors. It maintains a stable blood glucose level by taking up and storing glucose as glycogen (glycogenesis), breaking it down to glucose when needed (glycogenolysis) and forming glucose from non carbohydrate sources such as amino acids (gluconeogenesis). The liver plays an important role in drug elimination and detoxification and liver damage may be caused by many xenobiotics, such as alcohol and many medicines, malnutrition, infection and anemia.

Liver damage is a wide spread disease which, in most cases, involves oxidative 
stress and is characterized by a progressive evolution from steatosis to chronic hepatitis, fibrosis, cirrhosis and hepatocellular carcinoma. Although almost all tissues in the body have some ability to metabolize chemicals, smooth endoplasmic reticulum in liver is the principal "metabolic clearing house" for both endogenous substances. A group of enzyme located in the endoplasmic reticulum known as Cytochrome $\mathrm{P}-450$, is the most important family of metabolizing enzymes in the liver. It is the terminal oxidase component of an electron transport chain. In modern medicines, corticosteroids and immunosuppressant are commonly used to treat liver disease in allopathic form of medicines. But these drugs are associated with adverse effects such as immunosuppressant and bone marrow depression. However there are number of drugs employed in traditional system of medicine for the liver infections. (Manju Gowda et al., 2014).

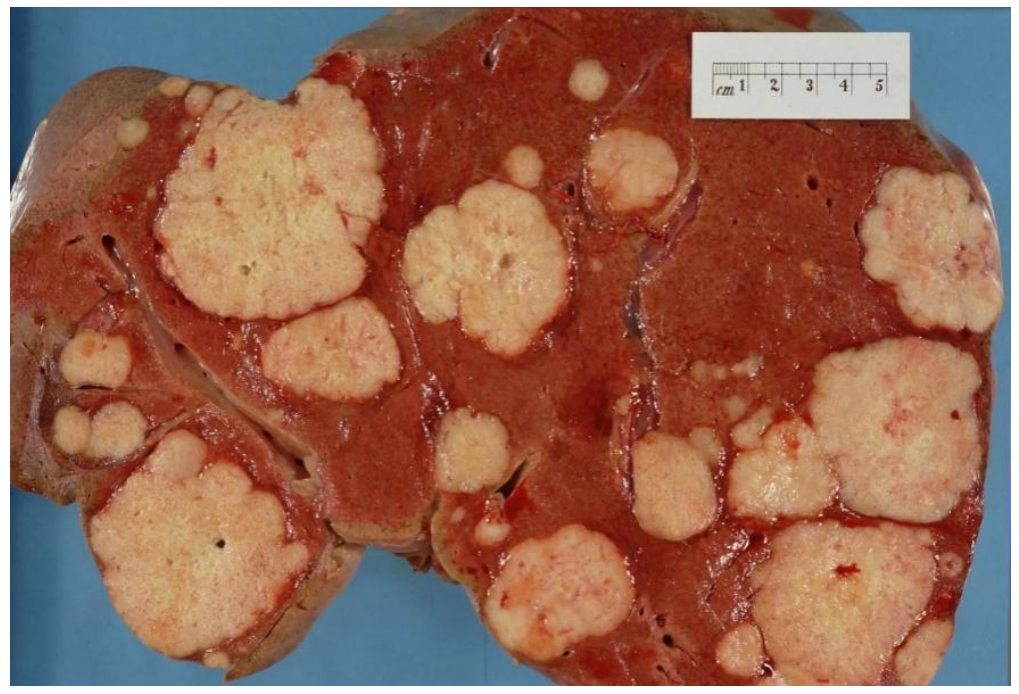

Cancerous Growth in Liver

In this study, the aqueous, methanolic and ethanolic extracts of G.lucidum is used to check out the anticancer activity of the mushroom by using the Liver cancer cell lines such as HepG2 and Vero cell lines. The hepatoma cell lines are frequently used as in vitro alternatives to primary human hepatocytes. Cell lines are characterized by their unlimited life span, stable phenotype, high availability, and easy handling. However, their major limitation is the lower expression of some metabolic activities compared with the hepatocytes. The anticancer and cytotoxic activities of methanol, ethanol \& aqueous extracts of Ganoderma lucidum was carried out by using the MTT Assay.
The MTT Cell viability Assay provides convenient, sensitive, quantitative and reliable assay for determining the number of viable cells in the cell culture. This homogeneous colorimetric assay is based on the principle of the conversion of tetrazolium salt, 3- (4, 5-dimethyl-2thiazolyl)-2, 5-diphenyl-tetrazolium bromide(MTT), a pale yellow substrate to formazon, a purple dye. This cellular reduction reaction involves the pyridine nucleotide cofactors NADH/ NADPH and is only catalyzed by living cells. The formazon product has the low aqueous solubility and is present as purple crystals. Dissolving the resulting formazon with solubilization buffer permits the convenient quantification of 
product formation. The intensity of product colour measured at 550- $620 \mathrm{~nm}$ is directly proportional to the number of living cells in the culture.

The main aim of this study includes to prepare the aqueous, methanolic and ethanolic extracts of Ganoderma lucidum. To perform the Cytotoxic activity of the mushroom extracts by using the Vero cell lines. To perform the Anticancer activity of the Ganoderma lucidum extracts introducing to the Liver Cancer Cell line such as HepG2 and also to perform the Antibacterial activity of G. lucidum extracts by Well diffusion method. To study the anticancer activity of methanolic, ethanolic and aqueous extracts from Ganoderma lucidum using invitro (Tissue culture). And also to study the antibacterial activity of G.lucidum extracts by well diffusion method.

\section{Materials and Methods}

\section{Collection of mushroom sample}

$250 \mathrm{gms}$ of the dried mycelia fruiting body of G.lucidum were collected from the Camillotek Private Ltd, Chennai.

\section{Preparation of mushroom extracts}

\section{Methanolic extracts of Ganoderma lucidum}

In the laboratory, the dried mushroom sample was powdered and stored in an air tight container for further use. The powder of Ganoderma lucidum (25gms) was extracted separately with the $250 \mathrm{ml}$ of methanol in a Soxhlet extractor for 6 hours. The extractions were repeated twice. The total extractions were filtered and the extracts were concentrated under the reduced pressure to dryness. The concentrated extracts were stored in the refrigerated condition for future research purpose.

\section{Ethanolic extracts of Ganoderma lucidum}

In the laboratory, the dried mushroom sample was powdered and stored in an airtight container for further use. The powder of Ganoderma lucidum (25gms) was extracted separately with the $250 \mathrm{ml}$ of ethanol in a Soxhlet extractor for 6 hours. The extractions were repeated twice. The total extractions were filtered and the extracts were concentrated under the reduced pressure to dryness. The concentrated extracts were stored in the refrigerated conditions for further use.

\section{Aqueous extracts of Ganoderma lucidum}

In the laboratory, the dried mushroom sample was powdered and stored in an airtight container for further use. The powder of Ganoderma lucidum (25gms) was extracted separately with the $250 \mathrm{ml}$ of distilled water in a Soxhlet extractor for 6 hours. The extractions were repeated twice. The total extractions were filtered and the extracts were concentrated under the reduced pressure to dryness. The concentrated extracts were stored in the refrigerated conditions for further use.

\section{Cell lines and culture}

Vero and Hep G2 cell lines were obtained from Veterinary College, Vepery, Chennai. The cells were maintained in Minimal Essential Medium supplemented with $10 \%$ FBS, Penicillin (100U/ml) and Streptomycin $(100 \mu \mathrm{g} / \mathrm{ml})$ in a humidified atmosphere of $50 \mu \mathrm{g} / \mathrm{ml} \mathrm{CO}_{2}$ at $37^{\circ} \mathrm{C}$.

In vitro assay for cytotoxicity/anti cancer activity (mtt assay) (mossman, 1983)

Cells $\left(1 \times 10^{5} /\right.$ well $)$ were placed in 24 - plates 
and incubated at $37^{\circ} \mathrm{C}$ with the $5 \% \quad \mathrm{CO}_{2}$ condition. After the cell reaches the confluence, the sample was removed from the well and washed with phosphatebuffered saline ( $\mathrm{pH} 7.4)$ or MEM without serum $100 \mu \mathrm{l} /$ well $(5 \mathrm{mg} / \mathrm{ml})$ of $0.5 \% 3-(4,5$ dimethyl-2-thiazolyl)-2, 5-diphenyl-tetrazolium Bromide (MTT) was added and incubated for 4 hours. After incubation, $1 \mathrm{ml}$ of DMSO was added in all the wells. The absorbance at $570 \mathrm{~nm}$ was measured with UV- Spectrophotometer using DMSO as the blank. Measurements were performed and the concentration required for a $50 \%$ inhibition (IC50) was determined graphically. The percentage of cell viability was calculated using the following formula:

$\%$ cell viability $=\mathrm{A} 570$ of treated cells $/$ A570 of control cells $\times 100$

Graphs are plotted using the \% of Cell viability at Y- axis and Concentration of the sample in X-axis. Cell control and sample control is included in each assay to compare the full cell viability assessments.

\section{Antibacterial activity of Ganoderma lucidum}

\section{Cultures}

Bacillus thuringiensis- MCC 2095 - MCC, NCCS, Pune, which causes hospital oriented infections and acts as commensals.

Pseudomonas flourescens- MTC 103MTCC Gene Bank, Chandigarh, which causes hospital oriented infections.

E.coli - Isolated from Urinary Tract Infection(UTI) patients

Micrococcus luteus - Isolated from the environmental source by open plate method.

\section{Antibacterial activity}

For determining the antibacterial activity of Ganoderma lucidum, Bacillus thuringiensis, Micrococcus luteus, Pseudomonas flourescens, and E.coli were selected randomly. The isolated bacterial colonies from the agar plates were inoculated into the sterile saline. The saline test tubes with the bacterial cultures were incubated at $37^{\circ}$ $\mathrm{C}$ for 2 hours. After 2 hours of incubation, the saline test tubes with the bacterial cultures were taken and compared with $0.5 \%$ Mac Farland's standard for the standardization of bacterial cultures. $200 \mathrm{ml}$ of Muller Hinton Agar was prepared by dissolving 7.6 gms of Muller Hinton agar in $200 \mathrm{ml}$ of sterile distilled water. The agar was sterilized by autoclaving at $121^{\circ} \mathrm{C}$ for 15 minutes. After the sterilization, the Muller Hinton Agar was poured onto the sterile petriplates aseptically. The agar was allowed to solidify for few minutes. With the help of sterile swabs, the each bacterial culture was swabbed onto the surface of the Muller Hinton Agar aseptically and allowed them to dry. The three wells $(1 \mathrm{~cm})$ were cut by using the sterile micropipette tips in equal intervals in each petriplate and marked. Then, the ethanol, methanol, and aqueous extracts of Ganoderma lucidum were taken. $25 \mu \mathrm{l}$ of various extracts of mushroom was inoculated onto the wells aseptically. After the inoculation, the plates were kept for incubation at $37^{\circ} \mathrm{C}$ for 24 hours. After 24 hours of incubation, the plates were checked for the zone of inhibition.

\section{Results and Discussion}

\section{MTT assay/ anticancer activity}

From the 3- (4, 5-dimethyl-2-thiazolyl)-2, 5diphenyl-tetrazolium bromide (MTT) Assay, cell viability (IC50) of $53.96 \%$ was 
obtained from the $15.6 \mu \mathrm{g} / \mathrm{ml}$ in the $1: 32$ dilution at the O.D value of 0.34 for the Methanolic extracts of the G.lucidum.

Cell viability (IC50) of $52.38 \%$ was obtained from the $31.2 \mu \mathrm{g} / \mathrm{ml}$ in the $1: 16$ dilution at the $\mathrm{O}$. D value of 0.33 for the Ethanol extracts of G.lucidum.

Similarly, cell viability (IC50) of $6.25 \mu \mathrm{g} / \mathrm{ml}$ was obtained from the $1: 8$ at the O.D value of 0.32 dilutions for the Aqueous extracts of the G.lucidum.

\section{Antibacterial activity}

After the incubation at $37^{\circ} \mathrm{C}$ for 24 hours, the MHA plates were checked for the Zone of Inhibition. The methanol extracts of $G$. lucidum showed $20 \mathrm{~mm}$ of zone formation in Pseudomonas flourescens (MTCC 103) and $10 \mathrm{~mm}$ of zone was observed from the methanol extracts of E.coli. Similarly, the Bacillus thuringiensis (MCC 2095) and
Micrococcus luteus was not subjected to any inhibition. Thus it shows negative action for those bacteria.

From the Anticancer and Antibacterial activity assays, it was proved that the Ethanol, Methanol and Aqueous extracts of G.lucidum consists of some phytochemical components, which controls the growth of micro organisms. The results for the Anticancer and Antibacterial activity were interpreted and described in the form of Tables, Charts and Figures.

The liver cancer cell lines which are used in the research purposes are HepG2, Huh 7, HeLA, SNU - 387, SNU -423, MC/9, Capan -1, Hep 3 -B, WCH -17, H4TG, RTH - 149, BRL 3A, etc (www.atcc.org). The available cell lines used for the present study, such as the Hep G2 and Vero cell lines supports the viral replication when transfected with $\mathrm{HBV}$ DNA.

Table.1 Cytotoxic effect of Methanol Extract on VERO Cell line

\begin{tabular}{|l|l|l|l|l|}
\hline S.No & Concentration $(\mu \mathrm{g} / \mathrm{ml})$ & Dilutions & $\begin{array}{l}\text { Absorbance } \\
(\mathrm{O} . \mathrm{D})\end{array}$ & $\begin{array}{l}\text { Cell Viability } \\
(\%)\end{array}$ \\
\hline 1 & $\mathbf{1 0 0 0}$ & Neat & $\mathbf{0 . 3 6}$ & $\mathbf{8 0 . 0 0}$ \\
\hline 2 & $\mathbf{5 0 0}$ & $\mathbf{1 : 1}$ & $\mathbf{0 . 3 8}$ & $\mathbf{8 4 . 4 4}$ \\
\hline 3 & $\mathbf{2 5 0}$ & $\mathbf{1 : 2}$ & $\mathbf{0 . 4 0}$ & $\mathbf{8 8 . 8 8}$ \\
\hline 4 & $\mathbf{1 2 5}$ & $\mathbf{1 : 4}$ & $\mathbf{0 . 4 1}$ & $\mathbf{9 1 . 1 1}$ \\
\hline 5 & $\mathbf{6 2 . 5}$ & $\mathbf{1 : 8}$ & $\mathbf{0 . 4 1}$ & $\mathbf{9 1 . 1 1}$ \\
\hline 6 & $\mathbf{3 1 . 2}$ & $\mathbf{1 : 1 6}$ & $\mathbf{0 . 4 2}$ & $\mathbf{9 3 . 3 3}$ \\
\hline 7 & $\mathbf{1 5 . 6}$ & $\mathbf{1 : 3 2}$ & $\mathbf{0 . 4 2}$ & $\mathbf{9 3 . 3 3}$ \\
\hline 8 & $\mathbf{7 . 8}$ & $\mathbf{1 : 6 4}$ & $\mathbf{0 . 4 3}$ & $\mathbf{9 5 . 5 5}$ \\
\hline 9 & Cell control & - & $\mathbf{0 . 4 5}$ & $\mathbf{1 0 0}$ \\
\hline
\end{tabular}


Table.2 Cytotoxic effect of Ethanol Extract on VERO Cell line

\begin{tabular}{|l|l|l|l|l|}
\hline S.No & Concentration $(\mu \mathrm{g} / \mathrm{ml})$ & Dilutions & $\begin{array}{l}\text { Absorbance } \\
(\text { O.D })\end{array}$ & $\begin{array}{l}\text { Cell Viability } \\
(\%)\end{array}$ \\
\hline 1 & $\mathbf{1 0 0 0}$ & Neat & $\mathbf{0 . 3 5}$ & $\mathbf{7 7 . 7 7}$ \\
\hline 2 & $\mathbf{5 0 0}$ & $\mathbf{1 : 1}$ & $\mathbf{0 . 3 6}$ & $\mathbf{8 0 . 0 0}$ \\
\hline 3 & $\mathbf{2 5 0}$ & $\mathbf{1 : 2}$ & $\mathbf{0 . 3 7}$ & $\mathbf{8 2 . 2 2}$ \\
\hline 4 & $\mathbf{1 2 5}$ & $\mathbf{1 : 4}$ & $\mathbf{0 . 4 0}$ & $\mathbf{8 8 . 8 8}$ \\
\hline 5 & $\mathbf{6 2 . 5}$ & $\mathbf{1 : 8}$ & $\mathbf{0 . 4 2}$ & $\mathbf{9 3 . 3 3}$ \\
\hline 6 & $\mathbf{3 1 . 2}$ & $\mathbf{1 : 1 6}$ & $\mathbf{0 . 4 3}$ & $\mathbf{9 5 . 5 5}$ \\
\hline 7 & $\mathbf{1 5 . 6}$ & $\mathbf{1 : 3 2}$ & $\mathbf{0 . 4 3}$ & $\mathbf{9 5 . 5 5}$ \\
\hline 8 & $\mathbf{7 . 8}$ & $\mathbf{1 : 6 4}$ & $\mathbf{0 . 4 4}$ & $\mathbf{9 7 . 7 7}$ \\
\hline 9 & Cell control & $\mathbf{-}$ & $\mathbf{0 . 4 5}$ & $\mathbf{1 0 0}$ \\
\hline
\end{tabular}

Table.3 Cytotoxic effect of Aqueous Extract on VERO Cell line

\begin{tabular}{|l|l|l|l|l|}
\hline S.No & Concentration $(\mu \mathrm{g} / \mathrm{ml})$ & Dilutions & $\begin{array}{l}\text { Absorbance } \\
(\text { O.D })\end{array}$ & $\begin{array}{l}\text { Cell Viability } \\
(\%)\end{array}$ \\
\hline 1 & $\mathbf{1 0 0 0}$ & Neat & $\mathbf{0 . 3 0}$ & $\mathbf{6 6 . 6 6}$ \\
\hline 2 & $\mathbf{5 0 0}$ & $\mathbf{1 : 1}$ & $\mathbf{0 . 3 1}$ & $\mathbf{6 8 . 8 8}$ \\
\hline 3 & $\mathbf{2 5 0}$ & $\mathbf{1 : 2}$ & $\mathbf{0 . 3 3}$ & $\mathbf{7 3 . 3 3}$ \\
\hline 4 & $\mathbf{1 2 5}$ & $\mathbf{1 : 4}$ & $\mathbf{0 . 3 7}$ & $\mathbf{8 2 . 2 2}$ \\
\hline 5 & $\mathbf{6 2 . 5}$ & $\mathbf{1 : 8}$ & $\mathbf{0 . 3 9}$ & $\mathbf{8 6 . 6 6}$ \\
\hline 6 & $\mathbf{3 1 . 2}$ & $\mathbf{1 : 1 6}$ & $\mathbf{0 . 4 1}$ & $\mathbf{9 1 . 1 1}$ \\
\hline 7 & $\mathbf{1 5 . 6}$ & $\mathbf{1 : 3 2}$ & $\mathbf{0 . 4 2}$ & $\mathbf{9 3 . 3 3}$ \\
\hline 8 & $\mathbf{7 . 8}$ & $\mathbf{1 : 6 4}$ & $\mathbf{0 . 4 2}$ & $\mathbf{9 3 . 3 3}$ \\
\hline 9 & Cell control & $\mathbf{-}$ & $\mathbf{0 . 4 5}$ & $\mathbf{1 0 0}$ \\
\hline
\end{tabular}

Table.4 Anticancer effect of Methanol Extract on HePG2 Cell line

\begin{tabular}{|l|l|l|l|l|}
\hline S.No & Concentration $(\mu \mathrm{g} / \mathrm{ml})$ & Dilutions & $\begin{array}{l}\text { Absorbance } \\
(\text { O.D })\end{array}$ & $\begin{array}{l}\text { Cell Viability } \\
(\%)\end{array}$ \\
\hline 1 & $\mathbf{1 0 0 0}$ & Neat & $\mathbf{0 . 0 4}$ & $\mathbf{6 . 3 4}$ \\
\hline 2 & $\mathbf{5 0 0}$ & $\mathbf{1 : 1}$ & $\mathbf{0 . 0 7}$ & $\mathbf{1 1 . 1 1}$ \\
\hline 3 & $\mathbf{2 5 0}$ & $\mathbf{1 : 2}$ & $\mathbf{0 . 1 1}$ & $\mathbf{1 7 . 4 6}$ \\
\hline 4 & $\mathbf{1 2 5}$ & $\mathbf{1 : 4}$ & $\mathbf{0 . 1 8}$ & $\mathbf{2 8 . 5 7}$ \\
\hline 5 & $\mathbf{6 2 . 5}$ & $\mathbf{1 : 8}$ & $\mathbf{0 . 2 3}$ & $\mathbf{3 6 . 5 0}$ \\
\hline 6 & $\mathbf{3 1 . 2}$ & $\mathbf{1 : 1 6}$ & $\mathbf{0 . 2 9}$ & $\mathbf{4 6 . 0 3}$ \\
\hline 7 & $\mathbf{1 5 . 6}$ & $\mathbf{1 : 3 2}$ & $\mathbf{0 . 3 4}$ & $\mathbf{5 3 . 9 6}$ \\
\hline 8 & $\mathbf{7 . 8}$ & $\mathbf{1 : 6 4}$ & $\mathbf{0 . 4 1}$ & $\mathbf{6 5 . 0 7}$ \\
\hline 9 & Cell control & $\mathbf{-}$ & $\mathbf{0 . 6 3}$ & $\mathbf{1 0 0}$ \\
\hline
\end{tabular}


Table.5 Anticancer effect of Ethanol Extract on HePG2 Cell line

\begin{tabular}{|l|l|l|l|l|}
\hline S.No & Concentration $(\mu \mathrm{g} / \mathrm{ml})$ & Dilutions & $\begin{array}{l}\text { Absorbance } \\
(\text { O.D })\end{array}$ & $\begin{array}{l}\text { Cell Viability } \\
(\%)\end{array}$ \\
\hline 1 & $\mathbf{1 0 0 0}$ & Neat & $\mathbf{0 . 0 8}$ & $\mathbf{1 2 . 6 9}$ \\
\hline 2 & $\mathbf{5 0 0}$ & $\mathbf{1 : 1}$ & $\mathbf{0 . 1 5}$ & $\mathbf{2 3 . 8 0}$ \\
\hline 3 & $\mathbf{2 5 0}$ & $\mathbf{1 : 2}$ & $\mathbf{0 . 2 1}$ & $\mathbf{3 3 . 3 3}$ \\
\hline 4 & $\mathbf{1 2 5}$ & $\mathbf{1 : 4}$ & $\mathbf{0 . 2 5}$ & $\mathbf{3 9 . 6 8}$ \\
\hline 5 & $\mathbf{6 2 . 5}$ & $\mathbf{1 : 8}$ & $\mathbf{0 . 2 8}$ & $\mathbf{4 4 . 4 4}$ \\
\hline 6 & $\mathbf{3 1 . 2}$ & $\mathbf{1 : 1 6}$ & $\mathbf{0 . 3 3}$ & $\mathbf{5 2 . 3 8}$ \\
\hline 7 & $\mathbf{1 5 . 6}$ & $\mathbf{1 : 3 2}$ & $\mathbf{0 . 4 0}$ & $\mathbf{6 3 . 4 9}$ \\
\hline 8 & $\mathbf{7 . 8}$ & $\mathbf{1 : 6 4}$ & $\mathbf{0 . 4 9}$ & $\mathbf{7 7 . 7 7}$ \\
\hline 9 & Cell control & - & $\mathbf{0 . 6 3}$ & $\mathbf{1 0 0}$ \\
\hline
\end{tabular}

Table.6 Anticancer effect of Aqueous Extract on HePG2 Cell line

\begin{tabular}{|l|l|l|l|l|}
\hline S.No & Concentration $(\mu \mathrm{g} / \mathrm{ml})$ & Dilutions & $\begin{array}{l}\text { Absorbance } \\
(\text { O.D })\end{array}$ & $\begin{array}{l}\text { Cell Viability } \\
(\%)\end{array}$ \\
\hline 1 & $\mathbf{1 0 0 0}$ & Neat & $\mathbf{0 . 1 0}$ & $\mathbf{1 5 . 8 7}$ \\
\hline 2 & $\mathbf{5 0 0}$ & $\mathbf{1 : 1}$ & $\mathbf{0 . 1 6}$ & $\mathbf{2 5 . 3 9}$ \\
\hline 3 & $\mathbf{2 5 0}$ & $\mathbf{1 : 2}$ & $\mathbf{0 . 2 2}$ & $\mathbf{3 4 . 9 2}$ \\
\hline 4 & $\mathbf{1 2 5}$ & $\mathbf{1 : 4}$ & $\mathbf{0 . 2 7}$ & $\mathbf{4 2 . 8 5}$ \\
\hline 5 & $\mathbf{6 2 . 5}$ & $\mathbf{1 : 8}$ & $\mathbf{0 . 3 2}$ & $\mathbf{5 0 . 7 9}$ \\
\hline 6 & $\mathbf{3 1 . 2}$ & $\mathbf{1 : 1 6}$ & $\mathbf{0 . 3 9}$ & $\mathbf{6 1 . 9 0}$ \\
\hline 7 & $\mathbf{1 5 . 6}$ & $\mathbf{1 : 3 2}$ & $\mathbf{0 . 4 4}$ & $\mathbf{6 9 . 8 4}$ \\
\hline 8 & $\mathbf{7 . 8}$ & $\mathbf{1 : 6 4}$ & $\mathbf{0 . 5 1}$ & $\mathbf{8 0 . 9 5}$ \\
\hline 9 & Cell control & $\mathbf{-}$ & $\mathbf{0 . 6 3}$ & $\mathbf{1 0 0}$ \\
\hline
\end{tabular}

Fig.1 Fruiting bodies of Ganoderma lucidum

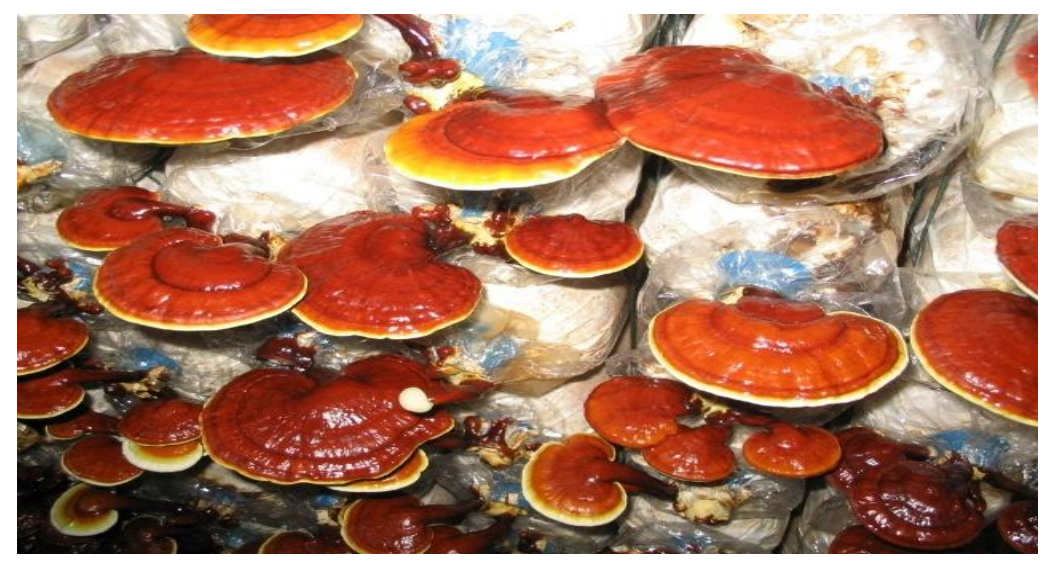


Fig.2 Dried mycelia \& powder of Ganoderma lucidum

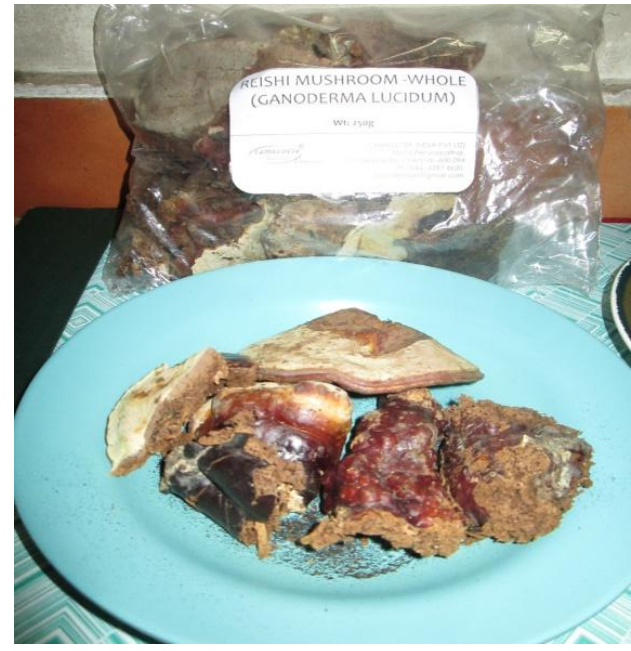

Fig.3 Soxhelet Extractor

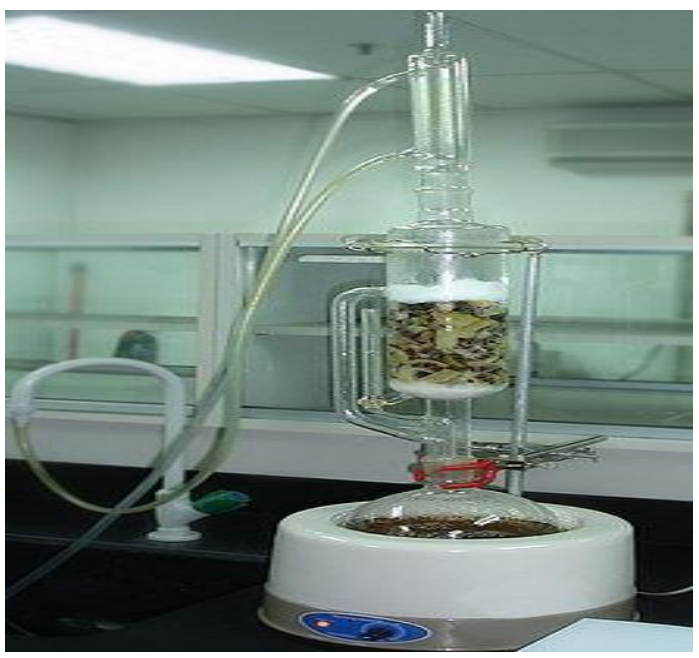

Fig.5 HepG2 cell line

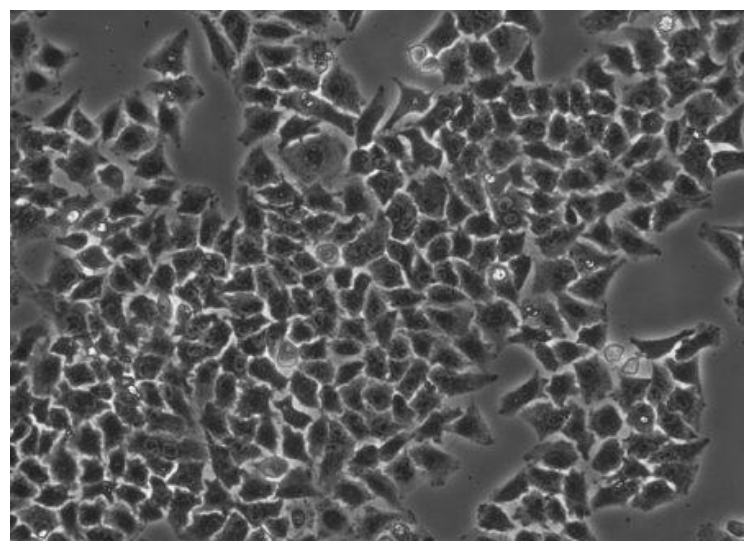

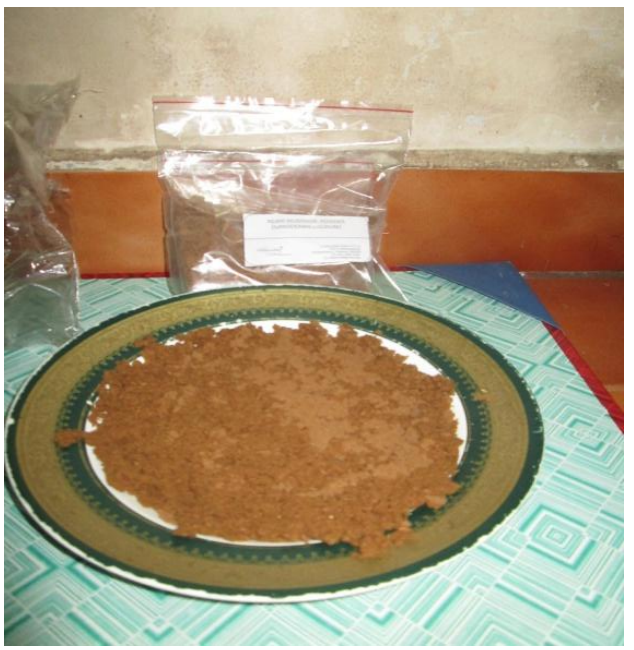

Fig.4 MTT Assay Microtitre Plate

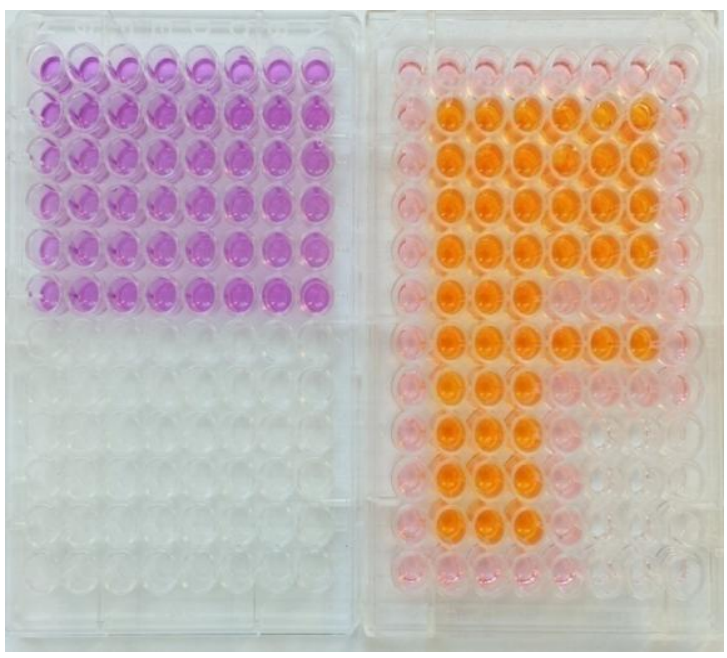

Fig.6 VERO cell line

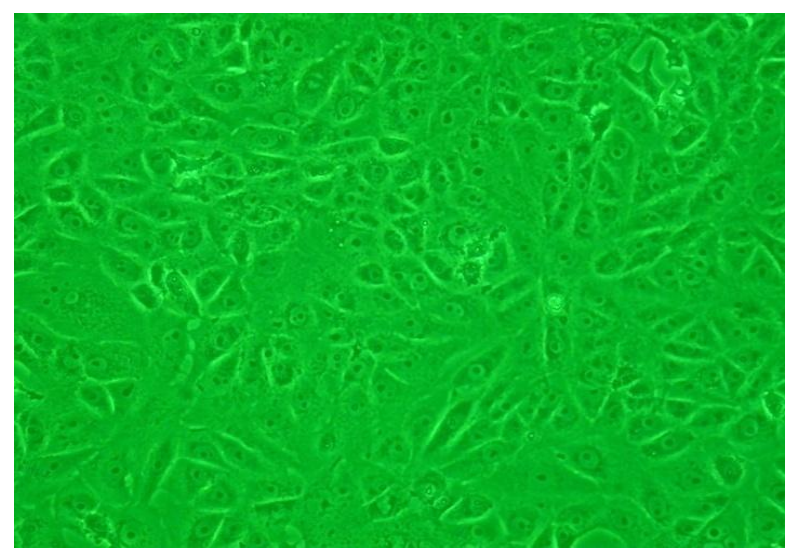


Fig.7 Cytotoxic effect of Methanol Extract on VERO Cell line Normal VERO Cell line

Toxicity-

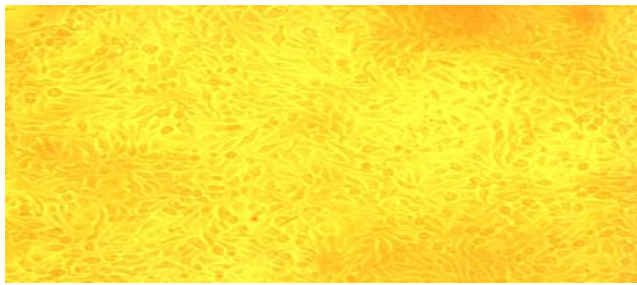

$1000 \mu \mathrm{g} / \mathrm{ml}$ Toxicity- $62.5 \mu \mathrm{g} / \mathrm{ml}$

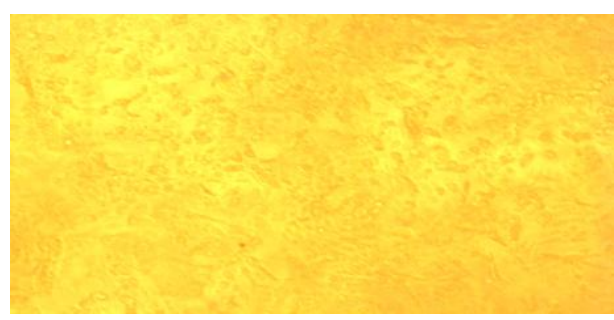

Toxicity-31.2 $\mu \mathrm{g} / \mathrm{ml}$

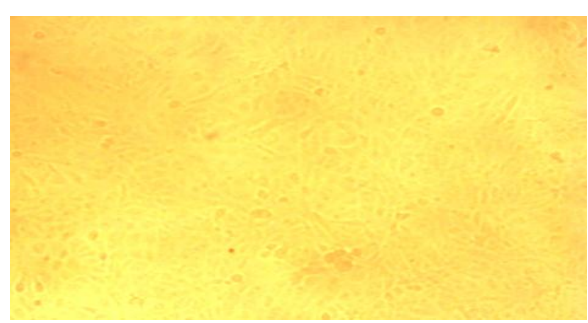

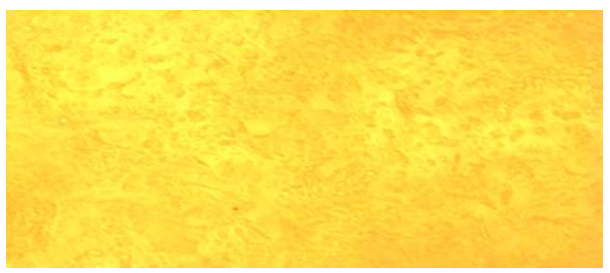

Toxicity-15.6 $\mu \mathrm{g} / \mathrm{ml}$

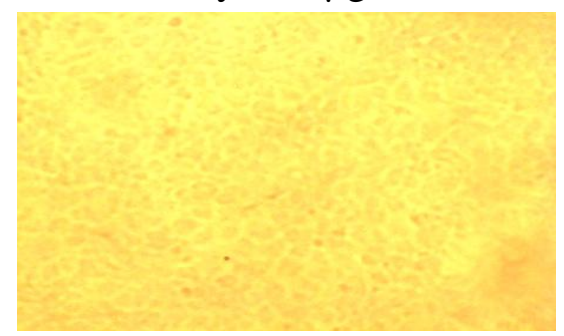

Fig.8 Cytotoxic effect of Ethanol Extract on VERO Cell line

Normal VERO Cell line

Toxicity-1000 $\mu \mathrm{g} / \mathrm{ml}$

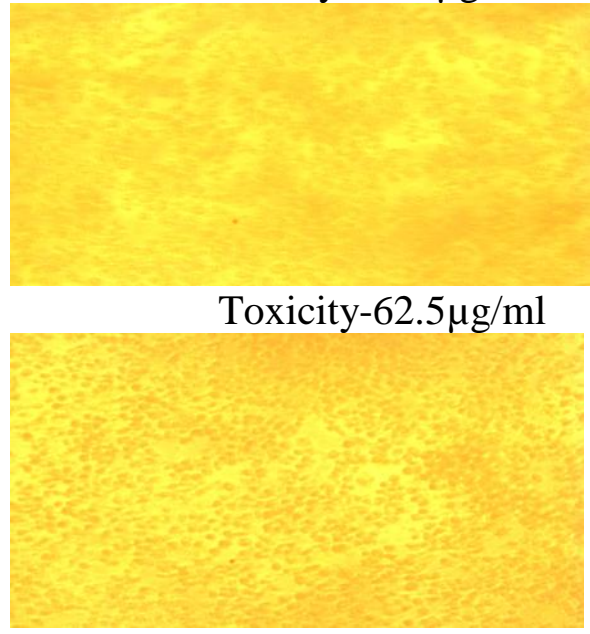

Toxicity- $125 \mu \mathrm{g} / \mathrm{ml}$

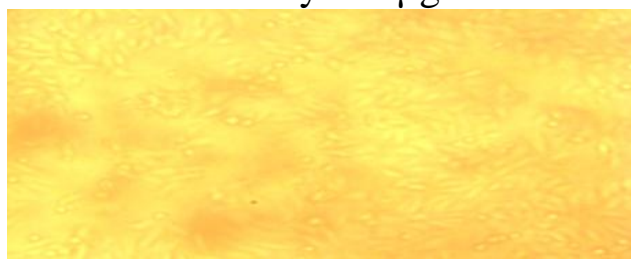

Toxicity-31.2 $\mu \mathrm{g} / \mathrm{ml}$

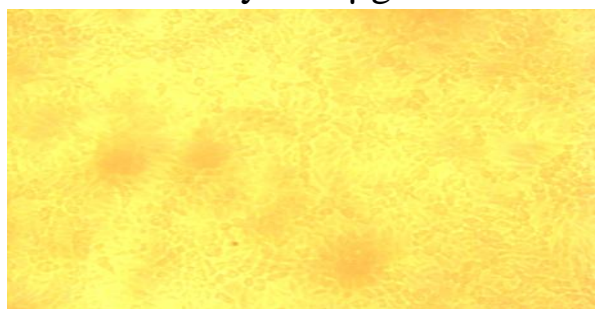


Fig.9 Cytotoxic effect of Aqueous Extract on VERO Cell line Normal VERO Cell line

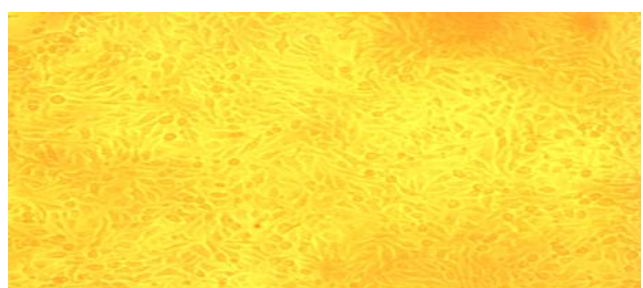

Toxicity-1000 $\mu \mathrm{g} / \mathrm{ml}$

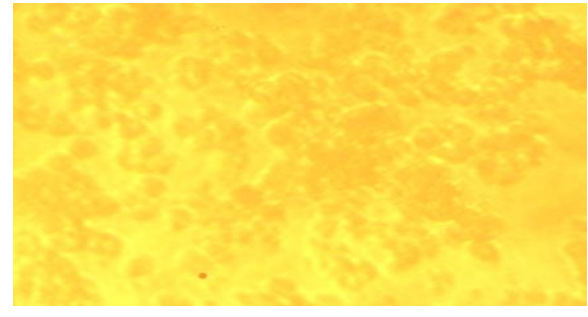

Toxicity-62.5 $\mu \mathrm{g} / \mathrm{ml}$

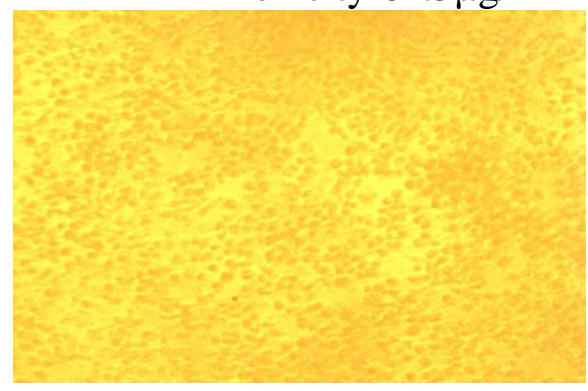

Toxicity- $125 \mu \mathrm{g} / \mathrm{ml}$

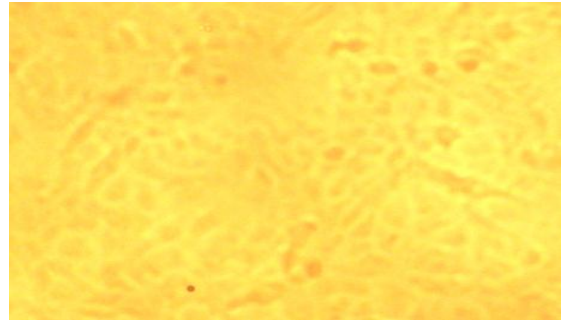

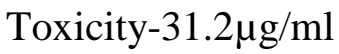

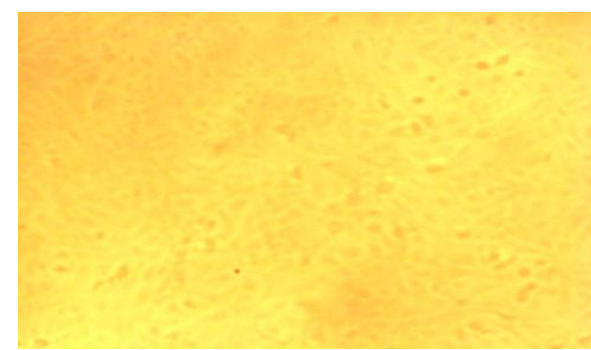

Fig.11 Antibacterial activity of G.lucidum extracts by well diffusion method

Figure 11.a Bacillus thuringiensis on Muller Hinton Agar (MHA)

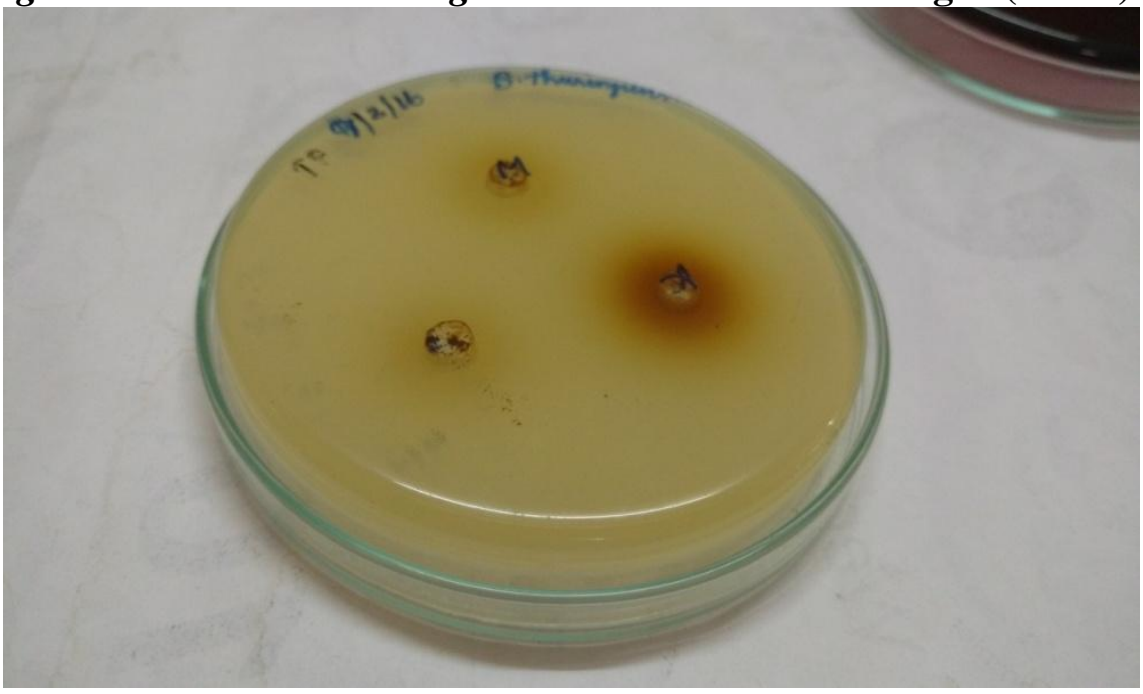


Figure11.b Micrococcus luteus on Muller Hinton Agar (MHA)

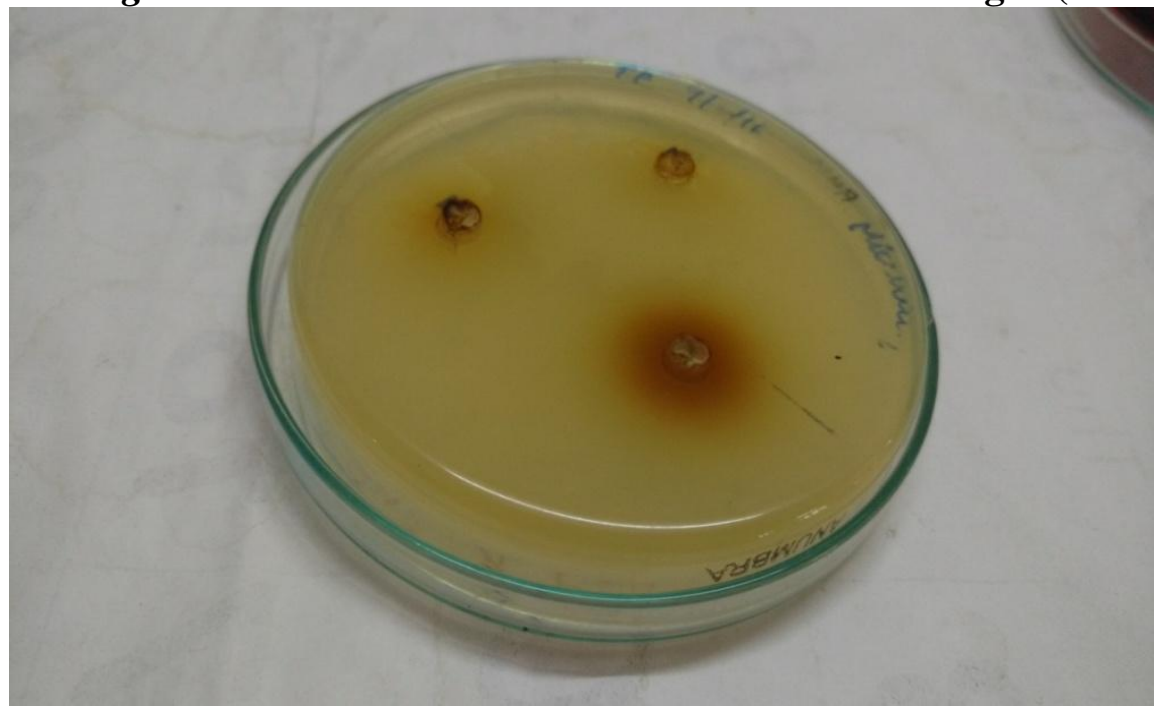

Figure 11.c Escherichia coli on Muller Hinton Agar (MHA)

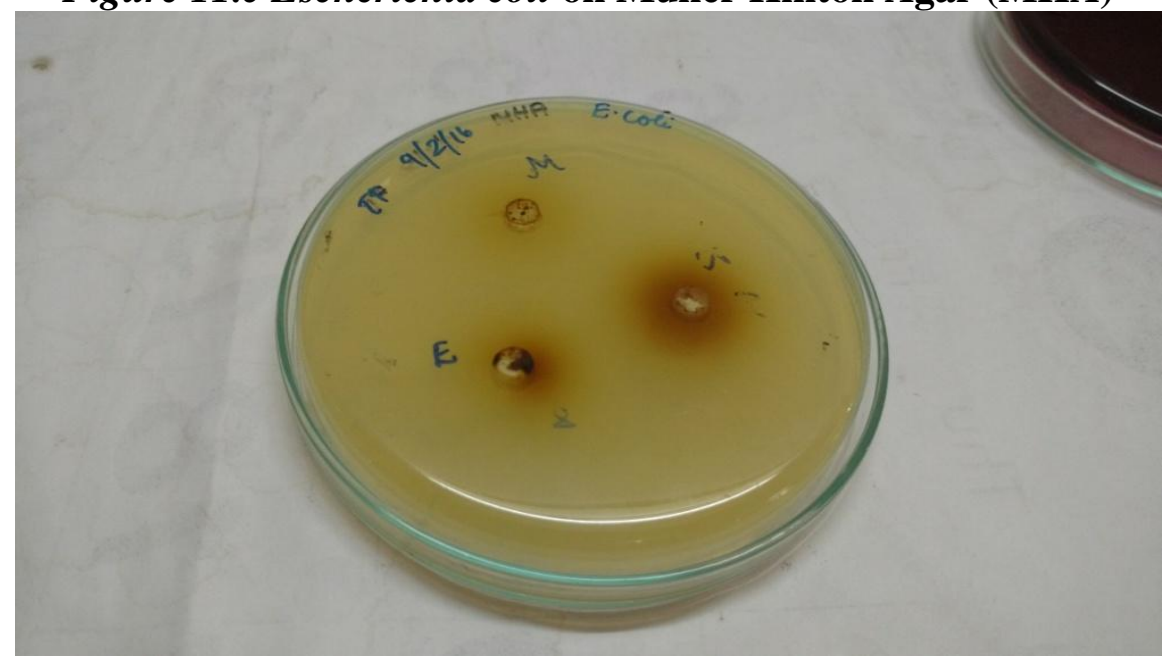

Figure 11.d Pseudomonas flourescens on Muller Hinton Agar (MHA)

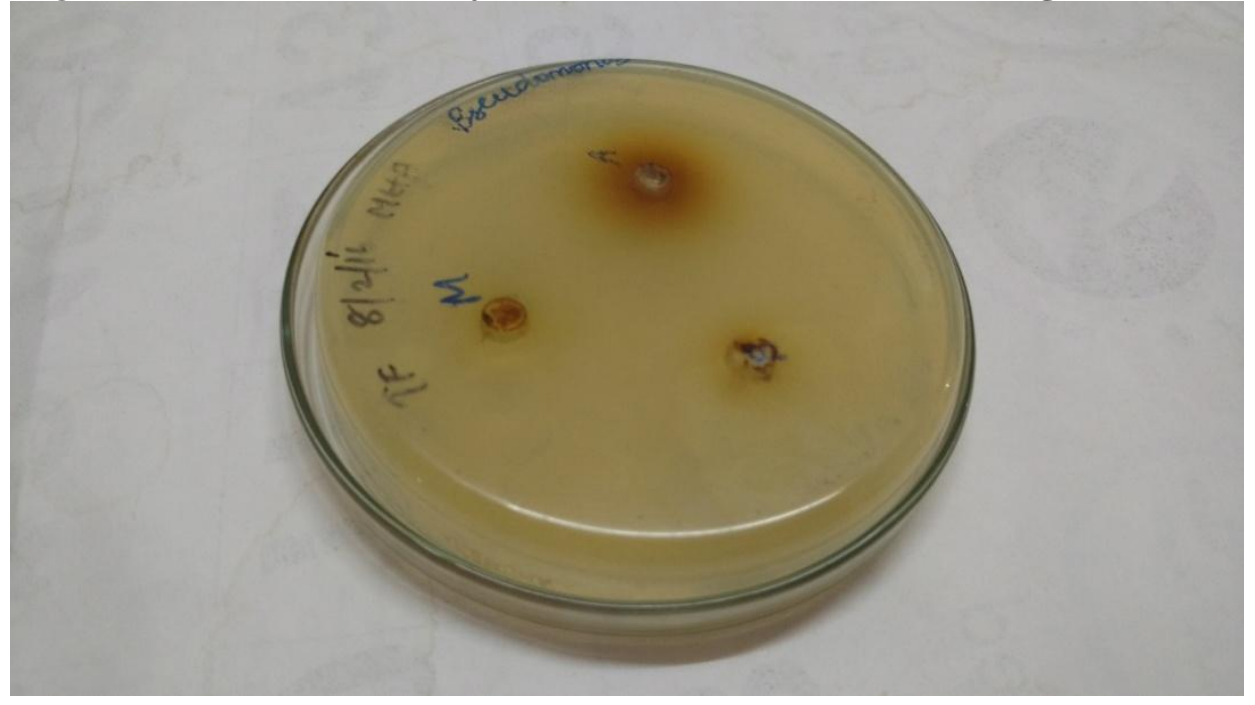


Chart.1 Cytotoxic Effect of Methanolic extracts on VERO cell line

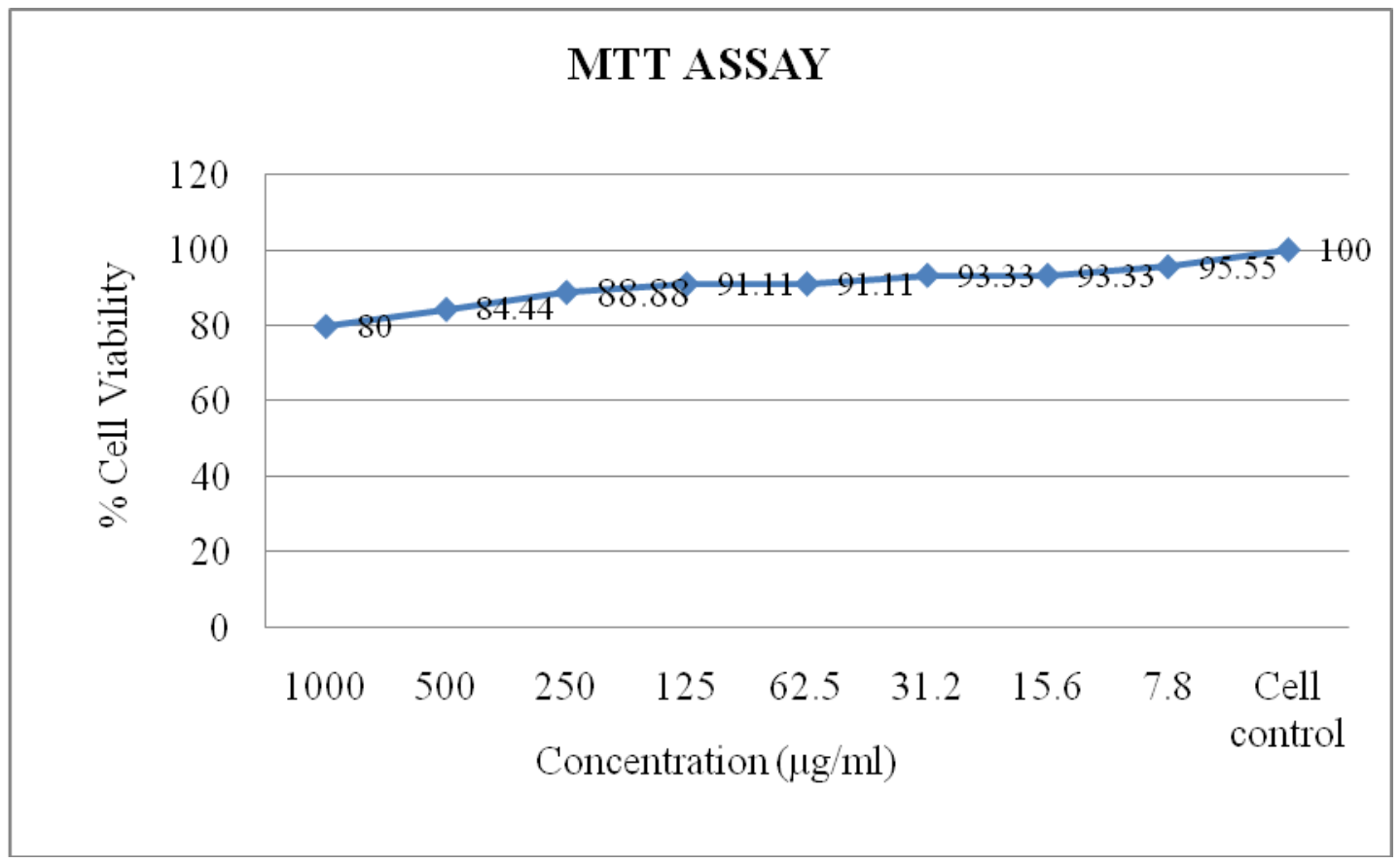

Chart.2 Cytotoxic Effect of Ethanolic extracts on VERO cell line

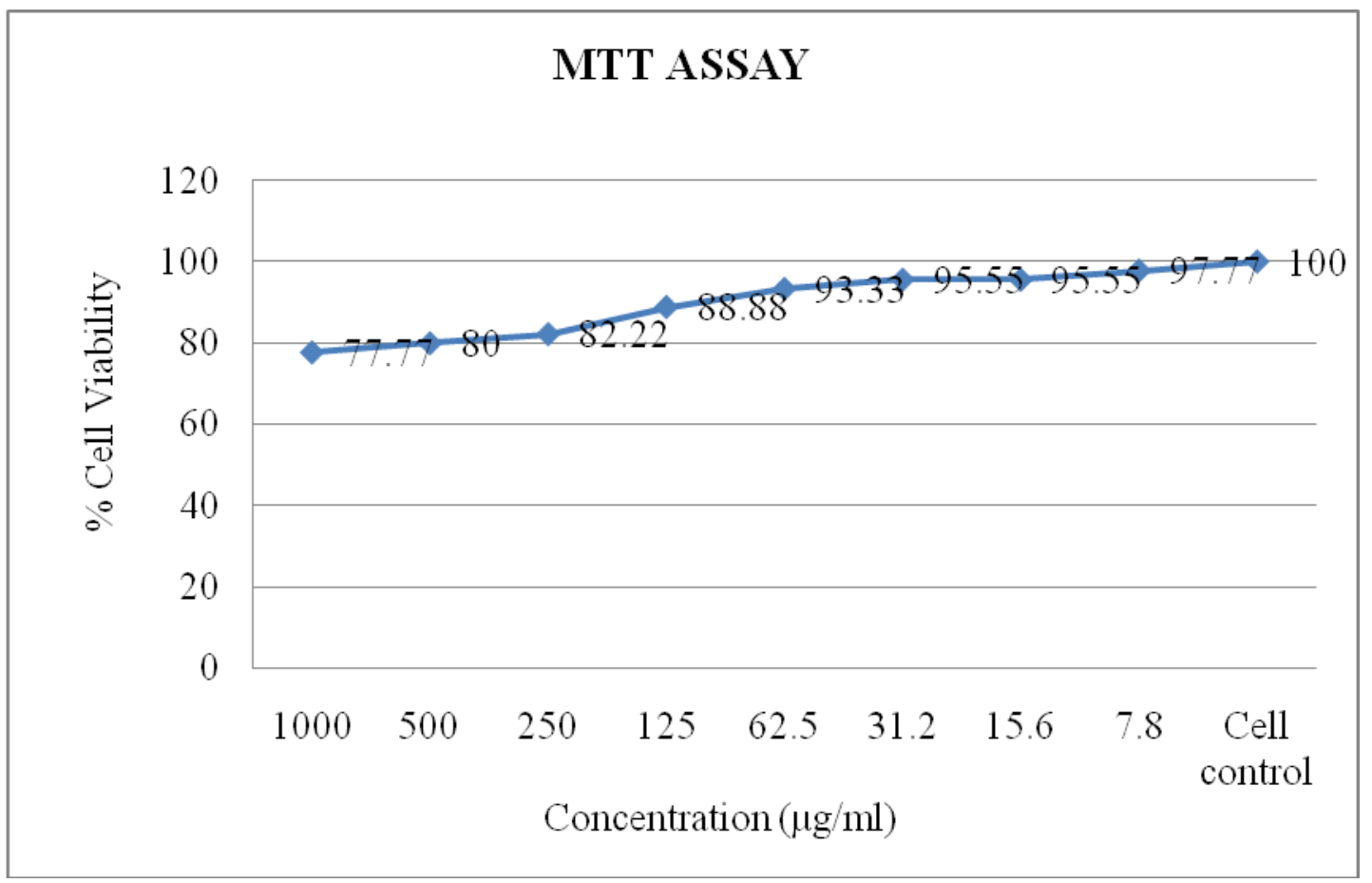


Chart.3 Cytotoxic Effects of Aqueous extracts on VERO cell line

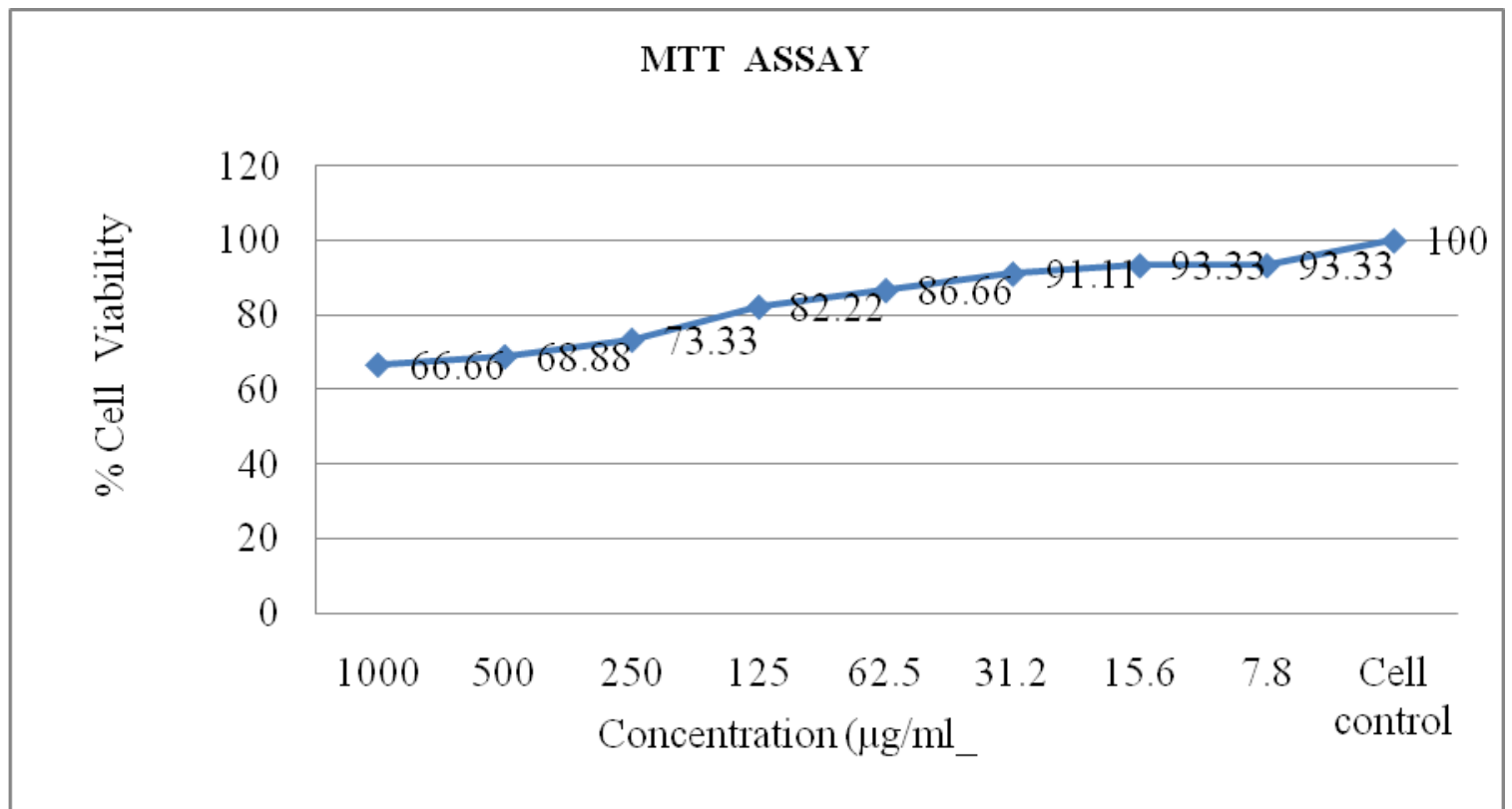

Chart.4 Anticancer Effect of Methanolic extracts on HepG2 cell line

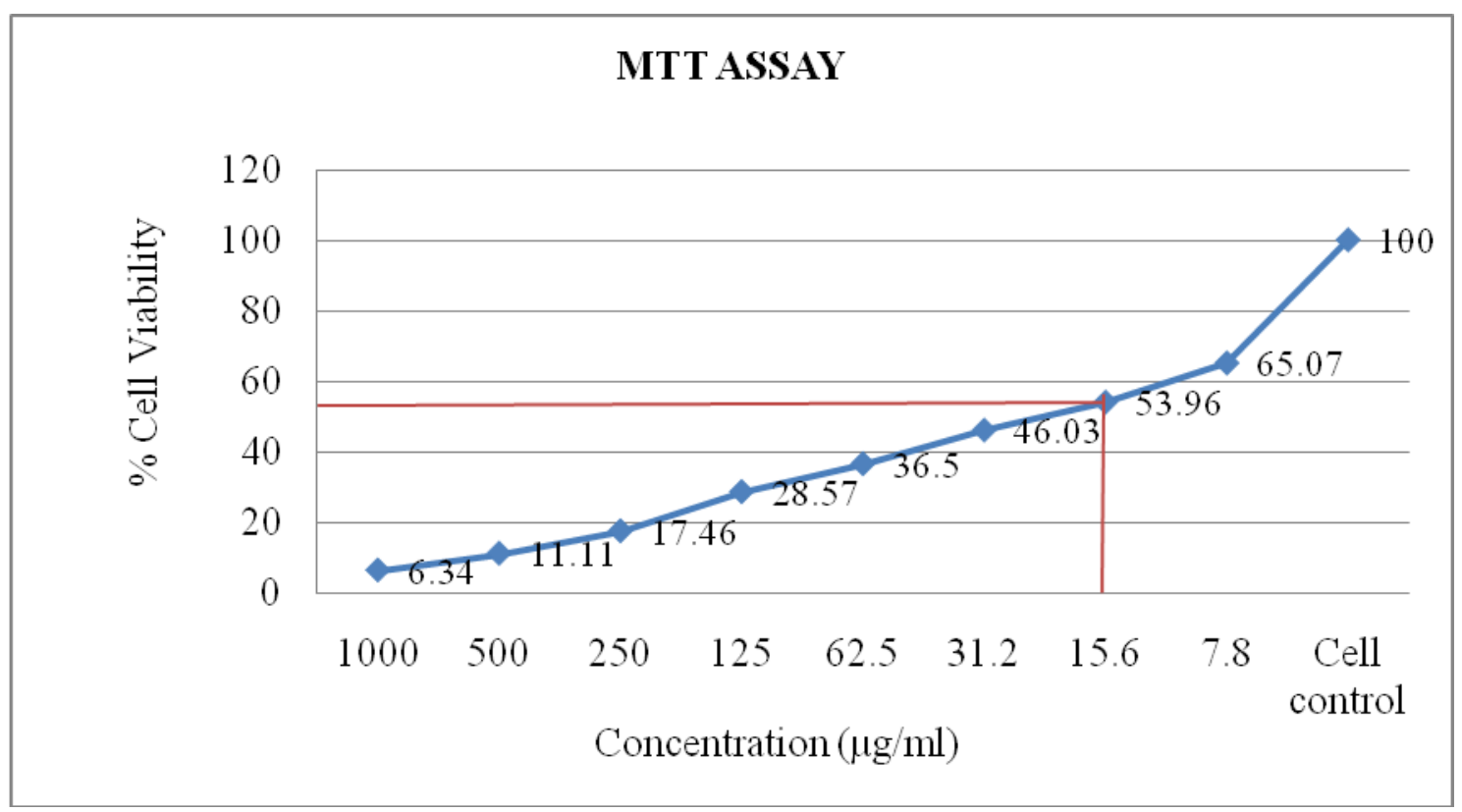


Chart.5 Anticancer Effect of Ethanolic extracts on HepG2 cell line

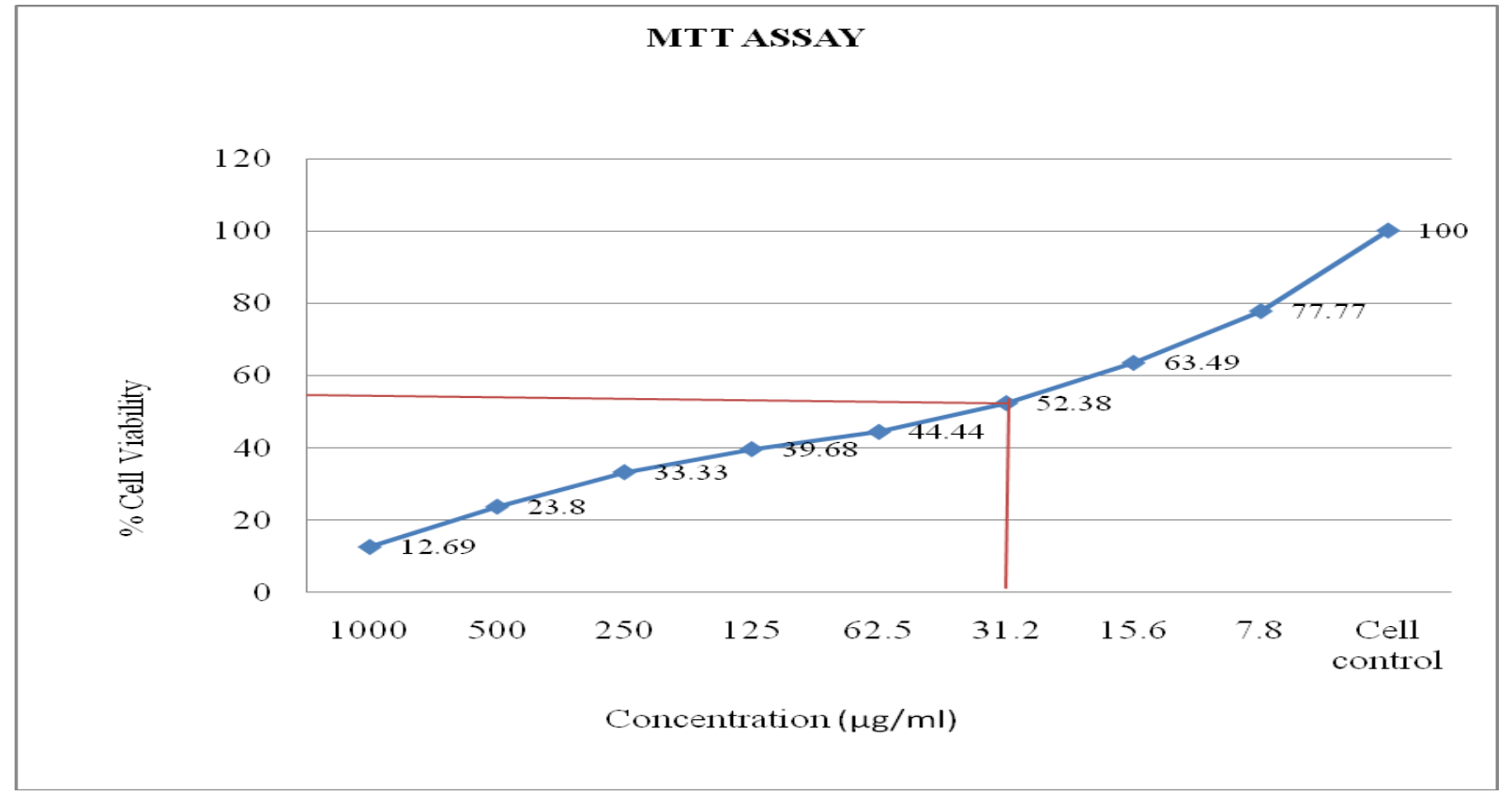

Chart.6 Anticancer Effects of Aqeuous extracts on HepG2 cell lines

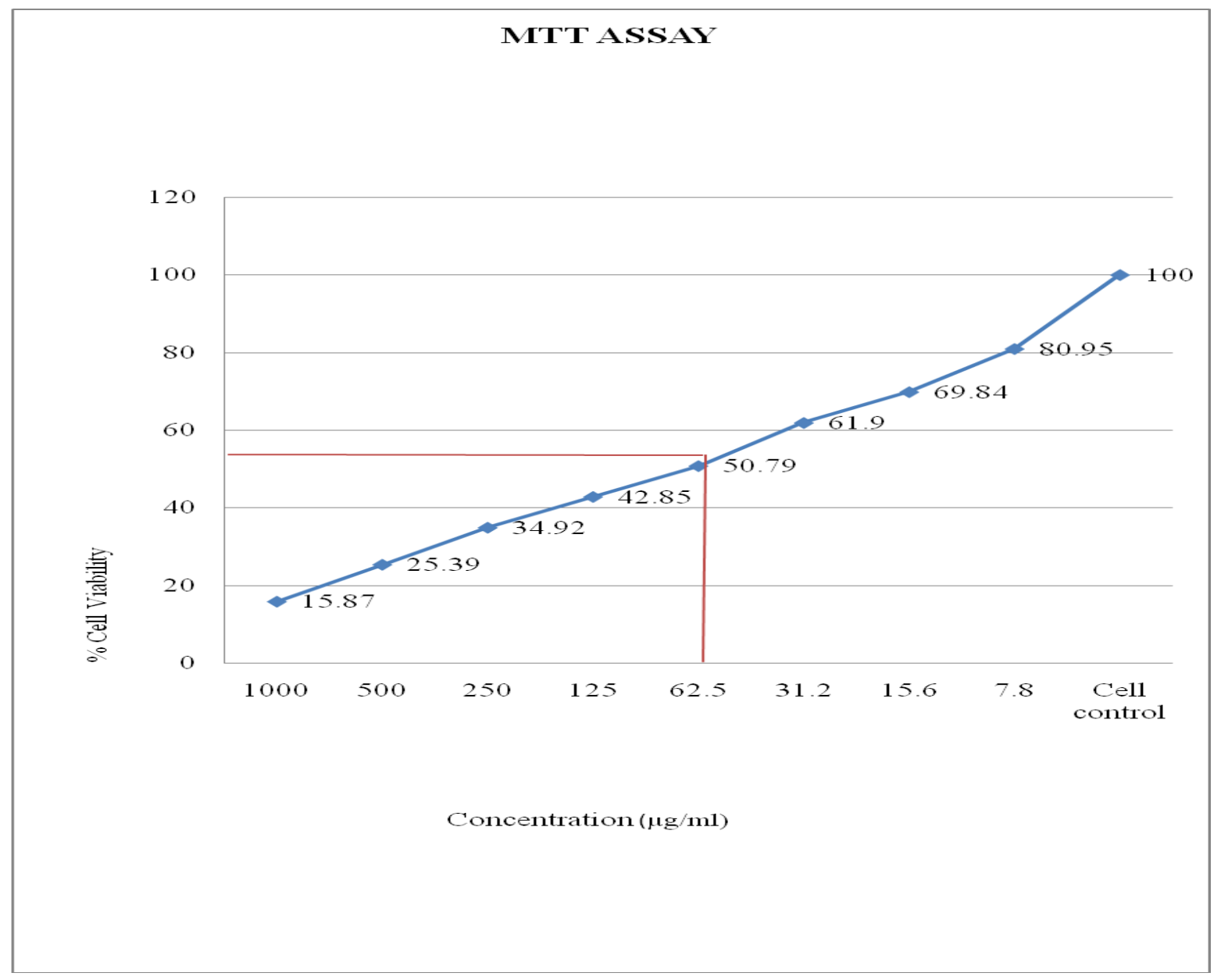


From the MTT Assay, it was observed that $53.96 \%$ of inhibition was obtained from the dilution of $15.6 \mu \mathrm{g} / \mathrm{ml}$ in methanolic extracts of G.lucidum, $52.38 \%$ of inhibition was obtained from the dilution of $31.2 \mu \mathrm{g} / \mathrm{ml}$ in ethanol extracts of G.lucidum, $50.75 \%$ of inhibition was obtained from the dilution of $62.5 \mu \mathrm{g} / \mathrm{ml}$ in aqeous extracts if G.lucidum, It was concluded that the methanolic extracts showed inhibition(IC 50) of $53.96 \%$ at the least dilution of $15.6 \mu \mathrm{g} / \mathrm{ml}$, when compared to the ethanolic and aqueous extracts of G.lucidum.

From the antibacterial study, the methanolic extract of G.lucidum showed about $20 \mathrm{~mm}$ of zone of inhibition in the Pseudomonas flourescens (MTCC 103) from the dilution of $25 \mu \mathrm{g} / \mathrm{ml}$ and $10 \mathrm{~mm}$ of zone of inhibition was observed in Escherichia coli, which was isolated from UTI patients from the dilution of $25 \mu \mathrm{g} / \mathrm{ml}$. The ethanolic and aqueous extracts were least effective against all the strains . as similar to the studies carried out by Jaya et al., 2014 and Maafi Rizwana Islam et al., 2015).

From these studies the methanolic extracts of Ganoderma lucidum can be fruitfully applied and used as the more effective and competent antimicrobial agents. Thus this edible mushroom can be used as antimicrobial agent in the expansion of new drug therapy for the liver diseases.

In conclusion, the Anticancer activity of methanolic, ethanolic and aqueous extracts of Ganoderma lucidum was performed by using MTT assay and the antibacterial activity was performed by well diffusion method.

The methanolic extracts of Ganoderma lucidum resulted in inhibition of cancer as well as the bacterial growth in both the Anticancer as well as Antibacterial activity testing at least dilutions. Thus the present study reveals that the methanolic extracts of Ganoderma lucidum may consist of effective bio active compounds when compared with aqueous and ethanolic extracts in treating the cancer and the bacterial infections.

In future, the molecular studies and related techniques can be carried out to study in detail about the active components which plays an important role in controlling and preventing multiplication of various cancer cells and infections caused by common micro organisms.

\section{References}

Adams, M., Christen, M., Plitzko, I., Zimmermann. S., Brun, R., Kaiser, M., Hamburger,M, 2010. Antiplasmodial lanostanes from the Ganoderma lucidum mushroom, J. Nat. Prod., 73:897-900.

Andreia, A.S., Anacharis, B.S.N., Adelar, B., Sandra, M.G.C., Eloa, A.K., Cristina, G.M.S., Rosane, M.P, 2013. Hepatoprotective Effects of Mushrooms, Molecules J., 18: 7609- 7630.

Andrej, J., Anita, T.S., Jiahua, J., Daniel, S, 2011. Ganodermanantriol lanostanoid triterpene from Ganoderma lucidum, suppresses the growth of colon cancer cells through $\beta$-Catenin signaling, Int. J. Oncol., 38: 761-767.

Daniel sliva, 2003. Ganoderma lucidum (Reishi) in Cancer Treatment, Integrative Cancer therapies, 2(4): 358-364.

Fenglin, Li., Yiming, Z., Zhijian, Z, 2011. Antihyperglycemic effect of Ganoderma lucidum Polysaccharides on Streptozotocin- Induced Diabetic Mice, Int. J. Mol. Sci., 12:6135-6145.

Ferreira, I.C.F.R., Vaz, J.A., Vasconcelos, M.H., \& Martins, A, 2010. Compounds from wild mushrooms with anti tumor potential, Anticancer Agents in Med. Chem., 10: 424-436. 
Gao, Y., Zhou, S., Chen, G, 2002. A phase I / II study of Ganoderma lucidum (Lingzhi, Reishi mushroom) extracts in patients with chronic hepatitis- B, Int. J. Med. Mush., Vol.4, 321-327.

Gao, Y., Zhou, S., Jiang, W., Huang, M., Dai, $\mathrm{X}, 2003$. Effects of Ganopoly, (a G.lucidum polysaccharide extract) on the immune functions in advanced stage cancer patients, Immunol. Invest., 32: 201-15.

$\mathrm{Gu}$, X. 1993. The pharmacology study of G.lucidum spores, Part III, Its effect on Immune function, Pharmocol. Clin. Chin. Mat. Med., 1: 11-3.

Guo-Liang, Z., Ye- Hong, W., Wei, N., HuiLing, T., Zhi-Bin, L, 2002.Hepatoprotective role of Ganoderma lucidum polysaccharide against BCG - induced immune liver injury in mice, World. J. Gasteroenterol., 8(4): 728-733.

Hanaoka, R., Ueno, Y., Tanaka, S., Nagai, K., Onitake, T., Yoshioka, K.,Chayama. K, 2011. The Water- Soluble Extract from Cultured Medium of Ganoderma lucidum,(Reishi), Mycelia (Designated as MAK) Amoliarates Murine Colitis Induced by Trinitrobenzene Sulphonic Acid, Scand. J. .Immun., 74, 454-462.

Hijikata, Y., Yashuhara, A., Sahashi, Y, 2005. Effect on an herbal formula containing Ganoderma lucidum on reduction of Herpes Zoster pain: a pilot clinical trial, J. Clin. Med., 33: 517-523.

Ivette, J.S.A., Tiffany, J.R.F., Yismeilin, R.F.M., Mercedes, L.V., Daniel, J.L.A.,Geronimo, M.M., Luis, A.C., Micelle, M.M.M. 2016. Ganoderma lucidum Combined with EGFR Tyrosine Kinase Inhibitor, Erlotinib Synergize to Reduce Inflammatory Breast Cancer Progression, J. Canc., Vol.7 (5): 500511.

Jan, R.H., Teng-Yi, L., Ya- chun, H., ShiuhSheng, L., Shih-Yen, L., Mingi, C., LiKuang, C., \& Yu-Lin, L, 2011. Immuno modulatory activity of G.lucidumderived polysaccharide on human monocytoid dendritic cells pulsed with Der p1 allergen, BMC. Immunol., 12:31.

Jaya, S., Saurabh, G., Sonam,M., \& Bharti, A, 2014. In-vitro evaluation of Antimicrobial activity of Ganoderma lucidum, Int. J. Adv. Res., Vol. Issue 6, 460-466.

Maafi, R.I., Omar, M., Moyen Uddin, PK., Md. Rubel, M., Kamrunnahar. 2015.Phytochemical and antibacterial activity screening of three edible mushrooms, Pleurotus ostreatus, Ganoderma lucidum and Lentinus edodes accessible in Bangladesh, Amer. J. Bio \& Life. Sci., 3(2): 31-35.

Majid, A., Negar, R. 2015. Ganoderma lucidum A potent source of Polysaccharide for human cancer prevention, Int. Nast. Canc. Symp., www.nastaransymposium/proceeding201 5.

Manju, Gowda. M.R., Gnanasekaran, D., Ashik, N. T., Antony, G, 2013. Evaluation of Hepatoprotective activity of extracts of Breynia Vitis Idaea (Burm.F) C.Fisher leaves by using Chang Liver Cell lines, Asian. J. Res. In. Chem. \& Pharm. Sci., 1(2): 166-177.

Masanori, N., Tatsuyuki, K., Katsuro, T., Akira, Y., Kyogo, I., Fumiko, K., Shoichiro, K., Kuniyoshi, S., Ryuichiro, K., Kei, M. 2008. Randomized clinical trial of ethanol extract of Ganoderma lucidum in men with lower urinary tract symptoms, Asian. J. Androl., 10(5): 777785.

Mei- Su, L., Zer-Ran, Y., Be-Jen, W., ChengChi, W., Yih- Ming, W., \& Macolm, K, 2015. Bio Active Constituent Characterization and Anti oxidant Activity of Ganoderma lucidum extract Fractionated by Super Critical Carbon Dioxide, Sains Malaysiana, 44(12): 1685- 1691.

Michelle, M.M.M., Raysa, R.A., Elisa, O.F., Luis, A.C., Suranganie, F.D. 2011.Ganoderma lucidum (Reishi) inhbits cancer cell growth and expression of key molecules in Inflammatory 
Breast Cancer, Nutr. Canc., 63(7): 10851094.

Paterson, R.R.M. 2006. Ganoderma - A Therapeutic Biofactory, Phytochem., 67.

Polishchuk, E.K., \& Kovalenko, A.G. 2009. Biological Activity of glycopolymers from basidiomycetes mushrooms, Ins. Mol. Bio \& Gen., Vol.25.

Ruhan, A., Mitsuru, S., Motonobu, G. 2007. Sub \& Supercritical Fluid Extraction of Bio active compounds from Ganoderma lucidum, Int. Conf. On. Eco Topia. Science.

Sandrina, A.H., Lillian, B., Anabela, M., Maria, J.R. P.Q., Celestino, S.B., Isabel, C.S.R.F. 2011. Fruiting Body spores and invitro produced by mycelium of Ganoderma lucidum from North East Portugal: A comparative study on the antioxidant potential of Phenolic \& polysaccharide extract.

Sarker, S.D., \& Nahar, L. 2007. Chemistry for Pharmacy Students General, Organic \& Natural Product Chemistry. England: John Wiley \& Sons. 283-259.

Selima, K., Aminul, I., Ugur, C., \& Narayanan, C.C, 2012. Research on mushroom as a potential sourceof Nutraceuticals: A review on Indian Perspective, Amer. J. Exp. Agr., 2(1): 4773.

Sullivan, R., Smith, J.E., \& Rowan, N.J, 2006. Medicinal mushrooms and cancer therapy: Translating a traditional practice into Western medicine, Perspectives in Biol. Med., 49: 159-170.

Sun- Hee, J., Sung- woo, C., Hyun- Min, Y., Kyung- Jeon, J., Chun- Ho, S.,CheolHong, K. 2014. Hepatoprotective evaluation of Ganoderma lucidum
Pharmacopuncture: In- vivo studies of Ethanol- induced Acute liver Injury, Jour. Phar., 17(3): 016-024.

Valadan, S., Ahmadi, R., Sadri, M., \& Mahdavi, E. 2014. Anti- Proliferative use of Ganoderma lucidum in Cell Culture on Vero cells, Int. Conf. On. Chem. Env. \& Bio. Sci., 17-18.

Wang, F., Zhongkhai, Z., Xiaochong, R., Yuyang, W., Rui, Y., Jinhua, L., \& Padraig, S, 2015 Effects of Ganoderma lucidum Spores intervention on glucose and lipid metabolism gene expression profiles in type 2 diabetic rats, Lipids in Health and Dis., 14: 49.

Xin, W., Xuan, Z., Dan, L., Ya Qing, L., ZhiBin, L., Guo-Liang, Z. 2007. Effects of Ganoderma lucidum polysaccharides on CYP2E1, CYP1A2 and CYP3A Activities in BCG- Immune Hepatic Injury in rats, Biol. Pharm. Bull., 30(9): 1702-1706.

Zengenni, L., Youjin, Y., Yutong, G., Rencai, W., Qiulong, H., \& Xingyao, X, 2014. Chemical characterization and Anti tumor Activities of Polysaccharides Extracted from Ganoderma lucidum, Int. J. Mol. Sci., 15: 9103-9116.

Zhi-Bin, L., Hui- na, Z. 2004. Anti-Tumor and Immuno regulatory activities of Ganoderma lucidum and its possible mechanisms, Acta. Pharmacol. Sin., 25(11): 1387-1395.

Zubling, L., Jing, L., Yifang, Z. 2005. Possible mechanism underlying the antiherpetic activity of a proteoglycan isolated from mycelia of Ganoderma lucidum in vitro, J. Biochem and Mol. Bio., 38: 34-40.

\section{How to cite this article:}

Thameem Fathima, A., and Reenaa, M. 2016. Anticancer and Antibacterial Activity of Ganoderma lucidum. Int.J.Curr.Microbiol.App.Sci. 5(10): 891-909.

doi: http://dx.doi.org/10.20546/ijcmas.2016.510.097 